
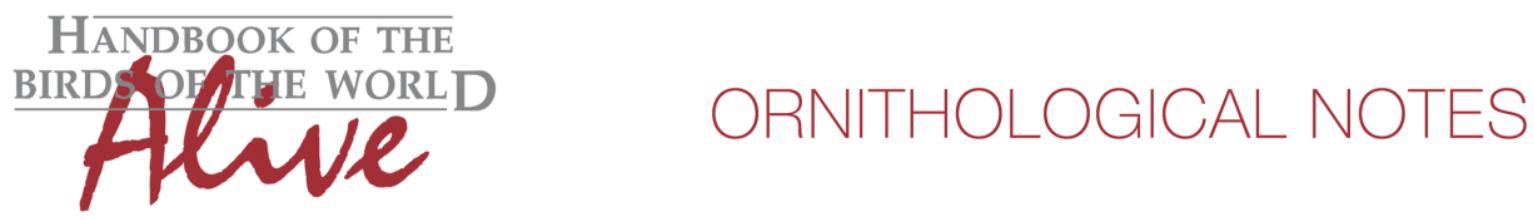

\title{
Notes on the vocalizations of White-fringed Antwren (Formicivora grisea)
}

Peter Boesman

In the following we briefly analyze and compare voice of the different races of White-fringed Antwren (Formicivora grisea). We also try to quantify the extent of any vocal differences using the criteria proposed by Tobias et al. (2010), as a support for taxonomic review.

We have made use of sound recordings available on-line from Xeno Canto (XC) and Macaulay Library (ML).

The difference in vocalization between 'Northern' and 'Southern' White-fringed Antwren has been discussed in Hilty (2003), but is decidedly more complex than suggested there.

In fact, all races have a comparable 'song' which consists of a single 'note', which is repeated for shorter or longer periods:

hondae: repeated note has the shape of a small letter' $n^{\prime}$

pace $\quad 0.17-0.25$ (measured here as the period, duration between 2 subsequent notes)

max. freq. $\quad 2100-2500 \mathrm{~Hz}$

note length $\quad 0.07-0.09 \mathrm{~s}$

freq. range. $1100-1300 \mathrm{~Hz}$

fumosa: repeated note has the shape of a small letter' $n^{\prime}$

pace $\quad 0.16-0.22$

max. freq. $\quad 1900-2000 \mathrm{~Hz}$

note length $\quad 0.06-0.07 \mathrm{~s}$

freq. range. $\quad 1000-1100 \mathrm{~Hz}$

intermedia: repeated note has the shape of a small letter' $n$ ' or ' $h$ ' (often only a few notes repeated)

pace $\quad 0.15-0.17$

max. freq. $\quad 2200-3000 \mathrm{~Hz}$

note length $\quad 0.06-0.07 \mathrm{~s}$

freq. range. $\quad 1100-1800 \mathrm{~Hz}$

orenocensis: repeated note has the shape of a small letter ' $h$ '

pace $\quad 0.14-0.15$

max. freq. $2900-3200 \mathrm{~Hz}$

note length $\quad 0.04-0.05 \mathrm{~s}$

freq. range. $1300-1600 \mathrm{~Hz}$

tobagensis: repeated note has the shape of a small letter' $n^{\prime}$

pace $\quad 0.22$

max. freq. $\quad 2500-2700 \mathrm{~Hz}$

note length $\quad 0.06 \mathrm{~s}$

freq. range. $\quad 1100-1200 \mathrm{~Hz}$ 

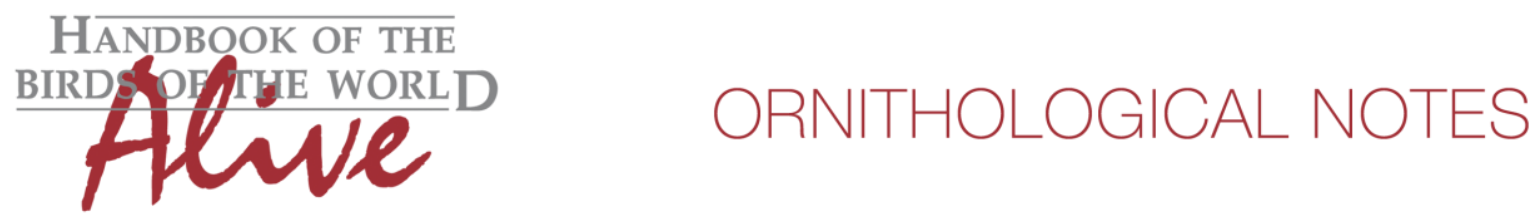

rufiventris repeated 'note' has the shape of a very long ' $h$ ' and preceded by a short sharply downslurred note (inaudible by human ear)

$\begin{array}{ll}\text { pace } & 0.29-0.32 \\ \text { max. freq. } & 3600-3900 \mathrm{~Hz} \\ \text { note length } & 0.04-0.07 \mathrm{~s} \\ \text { freq. range. } & 2600-3000 \mathrm{~Hz}\end{array}$

grisea: repeated 'note' has the shape of a sharply falling line, barely recognizable as an ' $h$ ' and often preceded by a short sharply down-slurred note or more complex shape (inaudible by human ear)

pace

0.31-0.46

max. freq. $\quad 3200-4400 \mathrm{~Hz}$

note length $\quad 0.06-0.08 \mathrm{~s}$

freq. range. $2500-3400 \mathrm{~Hz}$

when grouping the above taxa into two groups, we get:

'Northern' group ( $n>10)$ (hondae, fumosa, intermedia, orenocensis, tobagensis)

Repeated note has the shape of a small letter' $n$ ' or 'h' (Fig.1)

pace $\quad 0.14-0.25$

max. freq. $\quad 1900-3200 \mathrm{~Hz}$

note length $\quad 0.04-0.09 \mathrm{~s}$

freq. range. $\quad 1000-1800 \mathrm{~Hz}$

'Southern' group ( $\mathrm{n}>10)$ (rufiventris, grisea)

Repeated note has the shape of a sharply falling line, somewhat like an ' $h$ ' and often preceded by a short sharply down-slurred note or more complex shape (inaudible by human ear) (fig. 1)

pace $\quad 0.29-0.46$

max. freq. $\quad 3200-4400 \mathrm{~Hz}$

note length $\quad 0.04-0.08 \mathrm{~s}$

freq. range. $\quad 2500-3400 \mathrm{~Hz}$

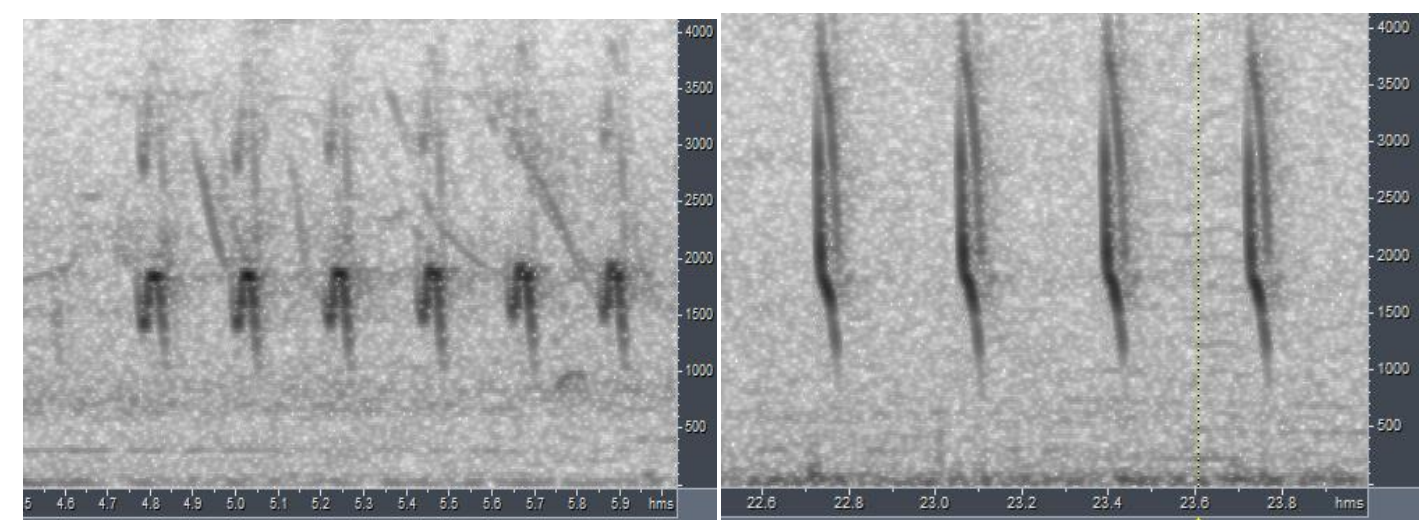

Figure 1: typical example of 'Northern' group (left, race fumosa) and 'Southern' group (right, race grisea) 

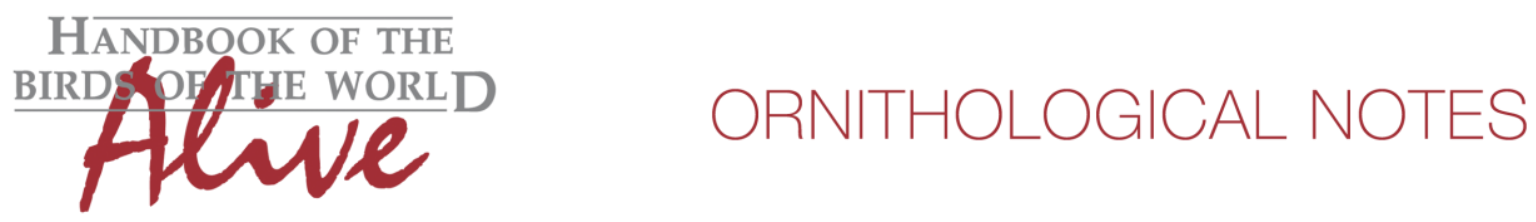

The main vocal differences between the two groups can thus be quantified based on frequency range and maximum frequency of repeated notes (score 2 or 3 ) and pace (score 1 or 2), leading to a total score of about 4.

Besides this 'song', there are other clear differences in voice. E.g., a very distinct vocalization is 'a long whistle followed by a trill'. This has been documented for hondae, intermedia and orenocensis, and would thus seem unique for 'Northern White-fringed Antwren'. Possibly there are more differences to be found when analyzing the complete vocabulary.

As a final remark, there is no info about albicincta, other than a description like 'repeated chup notes'

This note was finalized on 6th May 2015, using sound recordings available on-line at that moment. We would like to thank in particular the many sound recordists who placed their recordings for this species on XC and ML.

\section{References}

Hilty, S.L. (2003) Birds of Venezuela. Princeton University Press \& Christopher Helm, Princeton \& London

Tobias, J.A., Seddon, N., Spottiswoode, C.N., Pilgrim, J.D., Fishpool, L.D.C. \& Collar, N.J. (2010). Quantitative criteria for species delimitation. Ibis 152(4): 724-746.

\section{Recommended citation}

Boesman, P. (2016). Notes on the vocalizations of White-fringed Antwren (Formicivora grisea). HBW Alive Ornithological Note 46. In: Handbook of the Birds of the World Alive. Lynx Edicions, Barcelona. (retrieved from http://www.hbw.com/node/931754 on 29 April 2016). 